NO MORE SEPARATE SPHERES!

NEXT WAYE: WOMEN'S STUDIES BEYOND THE DISCIPLINES

A series edited by Inderpal Grewal, Caren Kaplan, \& Robyn Wiegman 


\section{NO MORE}

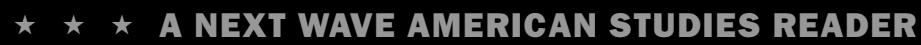




\section{SEPARATE SPHERES!}

EDITED BY CATHY N. DAVIDSON AND JESSAMYN HATCHER

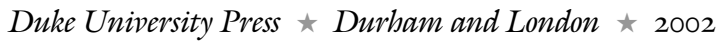


(C) 2002 DUKE UNIVERSITY PRESS

All rights reserved

Printed in the United States of

America on acid-free paper @

Designed by Amy Ruth Buchanan

Typeset in Carter \& Cone Galliard

by Tseng Information Systems, Inc.

Library of Congress Cataloging-in-

Publication Data appear on the last

printed page of this book. 
For our teachers and our students 
